\begin{tabular}{|l|l|l||}
\hline \multicolumn{2}{|c|}{ PublisherInfo } \\
\hline \hline PublisherName & $:$ & BioMed Central \\
\hline \hline PublisherLocation & $:$ & London \\
\hline \hline PublisherImprintName & $:$ & BioMed Central \\
\hline \hline
\end{tabular}

\title{
Operons in worms
}

\begin{tabular}{|l|c|l||}
\hline \multicolumn{2}{|c|}{ ArticleInfo } \\
\hline \hline ArticleID & $:$ & 4509 \\
\hline \hline ArticleDOI & $:$ & $10.1186 /$ gb-spotlight-20020620-01 \\
\hline \hline ArticleCitationID & $:$ & spotlight-20020620-01 \\
\hline \hline ArticleSequenceNumber & $:$ & 175 \\
\hline \hline ArticleCategory & $:$ & Research news \\
\hline ArticleFirstPage & $:$ & 1 \\
\hline \hline ArticleLastPage & $:$ & 2 \\
\hline \hline & & RegistrationDate : 2002-6-20 \\
\hline ArticleHistory & $:$ & OnlineDate \\
\hline \hline ArticleCopyright & $:$ & BioMed Central Ltd2002-6-20 \\
\hline \hline ArticleGrants & $:$ & \\
\hline \hline ArticleContext & $:$ & 130593311 \\
\hline \hline
\end{tabular}




\section{Jonathan B Weitzman}

Email: jonathanweitzman@hotmail.com

Operons contain multiple adjacent genes whose transcription is regulated by the transcription of a single polycistronic message. The processing of polycistronic pre-mRNA involves $3^{\prime}$ end formation and trans-splicing by the specialized SL2 small nuclear ribonucleoprotein particle. In the June 20 Nature, Blumenthal et al. describe a screen for SL2-containing mRNAs in the Caenorhabditis elegans genome (Nature 2002, 417:851-854). They used a probe enriched for SL2-containing mRNA to hybridize to microarrays containing over 17,000 genes. They selected around 1,200 genes, including many genes with known SL2-containing mRNAs. Most of these genes (86\%) are located downstream in operons, indicating a strong correlation between SL2 trans-splicing and downstream location in an operon. Blumenthal et al. estimated that the C. elegansgenome may contain as many as 1,068 operons, representing over 2,600 genes (or up to $15 \%$ of genes).

\section{References}

1. A second trans-spliced RNA leader sequence in the nematode Caenorhabditis elegans.

2. Nature, [http://www.nature.com] 